\title{
Ch2, a Novel Halophilic Archaeon from an Australian Solar Saltern
}

\author{
STEWART D. NUTTALL* AND MICHAEL L. DYALL-SMITH \\ Department of Microbiology, University of Melbourne, Parkville, Victoria 3052, Australia
}

\begin{abstract}
A novel halophilic archaeon, strain Ch2, was isolated from a marine solar saltern in Geelong, Australia. The fact that this organism had a dam-methylated genome suggested that it is closely related to the taxon that includes Halobacterium saccharovorum, Halobacterium sodomense, and Halobacterium trapanicum. A sequence analysis of the 16S rRNA gene (Ch2 has three copies of this gene) showed that $\mathrm{Ch} 2$ is phylogenetically equidistant from the genera Haloarcula and Haloferax and closely related to $H$. saccharovorum. The susceptibility of both $\mathrm{Ch} 2$ and $H$. saccharovorum to the recently isolated halophage HF2 supported the hypothesis that these two organisms are closely related.
\end{abstract}

Traditionally, the members of the family Halobacteriaceae have been classified on the basis of their biochemical and physiological properties and lipid compositions into six genera $(4,24)$. More recently, sequence comparisons of the small-subunit rRNAs have gained importance in classification. Using this approach, Lodwick et al. (13) suggested that up to nine halobacterial genera may be justified. The genus Halobacterium contains some of the best-characterized examples of these organisms, including Halobacterium salinarium and related strains (4). The validly named species Halobacterium saccharovorum, Halobacterium sodomense, and Halobacterium trapanicum form a separate taxon based on possession of dam-methylated genomes (12); this classification is supported by sequence data $(7,13)$. However, until a comprehensive taxonomic review has determined the true positions of these species, they remain species incertae sedis (4).

In a study to isolate halobacterial bacteriophages, we isolated both a phage (HF2) and a susceptible host (Ch2) from a solar saltern on Corio Bay near Geelong, Victoria, Australia. The bacterial host had many features typical of halobacteria and was easily cultivated. In this paper we describe the characterization of strain $\mathrm{Ch} 2$ as a new isolate and discuss its relationship to Halobacterium saccharovorum.

\section{MATERIALS AND METHODS}

Bacterial strains. Haloferax phenon $\mathrm{K}$ isolate Aa2.2 (6,

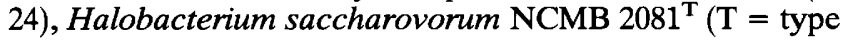
strain) (23), Halobacterium halobium NCMB 777, and Haloferax volcanii NCMB $2012^{\mathrm{T}}$, which were obtained from the National Collection of Marine Bacteria, Aberdeen, Scotland, and Haloarcula vallismortis ATCC $29715^{\mathrm{T}}$ were used as reference strains in biochemical tests and chromosomal DNA digestions. Escherichia coli $\mathrm{K}-12$ strains DH5 $\alpha$ and DH5 $\alpha \mathrm{F}^{\prime}$ were supplied by Bethesda Research Laboratories and were used in all transformations.

Media and growth conditions. A solution containing $25 \%$ (wt/vol) artificial salt water (SW) was prepared as described previously (6). This stock solution was diluted to a concentration of $18 \%(\mathrm{vol} / \mathrm{vol})$ and used to prepare both modified growth medium (MGM), which contained $18 \%$ (vol/vol) SW, $15 \mathrm{mM}$ Tris- $\mathrm{HCl}(\mathrm{pH} 7.5), 0.1 \%$ (wt/vol) yeast extract

\footnotetext{
* Corresponding author.
}

(Oxoid), and $0.5 \%$ (wt/vol) peptone (Oxoid), and SW-glucose minimal medium, which contained $18 \%$ (wt/vol) SW, 15 $\mathrm{mM}$ Tris- $\mathrm{HCl}$ (pH 7.5), 1\% (wt/vol) glucose, and $0.72 \mathrm{mM}$ $\mathrm{NaH}_{2} \mathrm{PO}_{4}$. In experiments in which the magnesium ion concentration was adjusted, $\mathrm{MgSO}_{4}$ was replaced by $0.19 \mathrm{M}$ $\mathrm{Na}_{2} \mathrm{SO}_{4}$ and the $\mathrm{MgCl}_{2}$ concentration was varied. For solid media, $15 \mathrm{~g}$ of agar (Difco) per liter was added. E. coli strains were grown and selected on standard media (1).

Anaerobic conditions were achieved by incubating cultures under a layer of oil (liquid cultures) or in anaerobic jars $\left(5 \% \mathrm{H}_{2}, 10 \% \mathrm{CO}_{2}, 85 \% \mathrm{~N}_{2}\right)$. Tests for indole, for catalase and oxidase activities, and for motility were performed by standard procedures (3). Antibiotic susceptibility tests (disc method) and carbohydrate utilization tests were performed as described by Rodriguez-Valera et al. (17) except that solid MGM was used in the antibiotic assays.

PCR amplification of the 16S rRNA gene coding sequence. Genomic DNA was isolated from strain $\mathrm{Ch} 2$ cultures by the hexadecyltrimethyl ammonium bromide- $\mathrm{NaCl}$ method (1). Two oligonucleotide primers, which were complementary to opposite strands of the 16S rRNA termini (for positions see Fig. 3), were designed by using the previously published sequence of Halobacterium salinarium (8). Polymerase chain reaction (PCR) amplification of the Ch2 16S rRNA

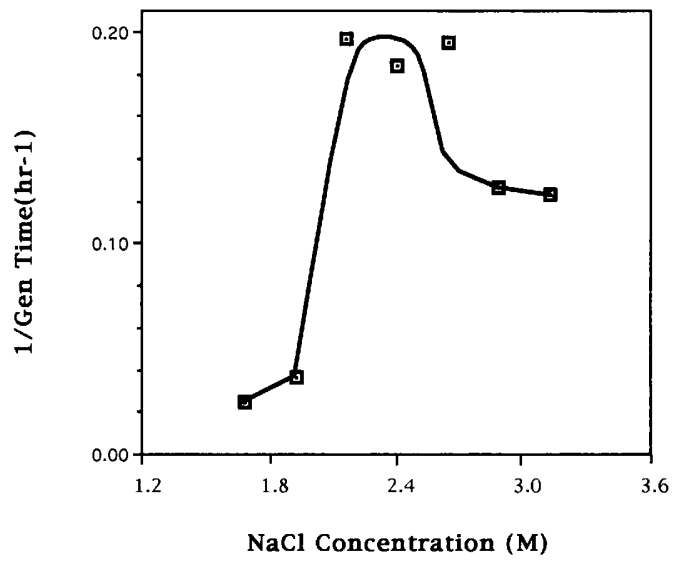

FIG. 1. Effect of $\mathrm{NaCl}$ concentration on the growth rate of strain $\mathrm{Ch} 2$. The medium contained $1 \mathrm{~g}$ of yeast extract per liter and $5 \mathrm{~g}$ of peptone per liter and was buffered to $\mathrm{pH}$ 7.5. The culture was incubated at $37^{\circ} \mathrm{C}$ in an orbital shaker (100 rpm). Gen Time, generation time. 


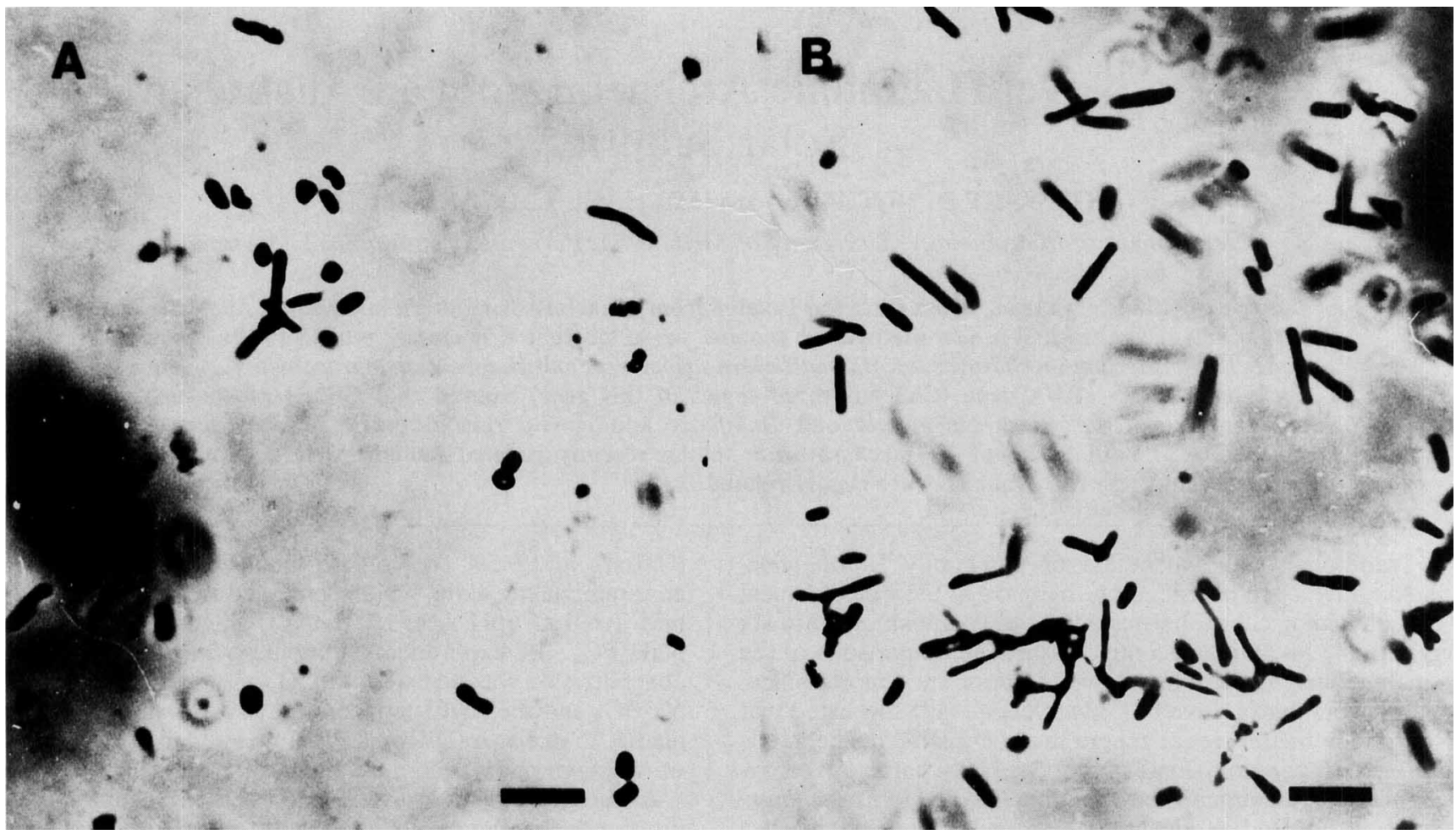

FIG. 2. Phase-contrast photomicrographs of $\mathrm{Ch} 2$ cells. (A) Early-logarithmic-phase culture containing pleomorphic forms. (B) Stationaryphase culture. Long rods are the predominant morphological type. Bars $=5 \mu \mathrm{m}$.

gene with Taq DNA polymerase (Pharmacia) was performed as described by Sambrook et al. (19) by using 30 cycles consisting of $1 \mathrm{~min}$ at $94^{\circ} \mathrm{C}, 2 \mathrm{~min}$ at $50^{\circ} \mathrm{C}$, and $4.5 \mathrm{~min}$ at $72^{\circ} \mathrm{C}$.

Cloning and sequence analysis. The amplified 16S rRNA gene (length, approximately $1,500 \mathrm{bp}$ ) was isolated from an agarose gel, ligated into the SmaI site of plasmid pUC19, and introduced into $E$. coli $\mathrm{DH} 5 \alpha$. Several clones were studied by restriction analysis, and fragments were subcloned into
M13mp19 vectors. A universal primer and several 16Sspecific primers described previously (6) were used for sequencing (20). Comparison sequences were obtained from the rRNA sequence data base (15) or from the study of Oren et al. (16) or had been determined previously by us $(6,7)$. These sequences were aligned by using CLUSTAL V (5) and were analyzed by using the phylogeny inference package of Felsenstein (PHYLIP, version 3.4) (2).

Southern analysis of Ch2 $16 \mathrm{~S}$ rRNA genes. Ch2 genomic

TABLE 1. Characteristics of strain $\mathrm{Ch} 2$ and related species

\begin{tabular}{|c|c|c|c|c|}
\hline Characteristic & $\begin{array}{l}\text { Halobacterium } \\
\text { saccharovorum }^{a}\end{array}$ & $\begin{array}{c}\text { Halobacterium } \\
\text { sodomense }^{b}\end{array}$ & $\begin{array}{c}\text { Halobacterium } \\
\text { trapanicum }^{b}\end{array}$ & Strain Ch2 \\
\hline dam methylation & + & + & + & + \\
\hline Cell morphology & Rods & Rods & Pleomorphic & Pleomorphic \\
\hline Motility & + & + & - & + \\
\hline Gas vesicles present & - & - & $\mathrm{ND}^{c}$ & - \\
\hline Minimum $\mathrm{NaCl}$ concn required for growth $(\mathrm{M})$ & 1.5 & 0.5 & ND & 2.2 \\
\hline $\mathrm{Mg}^{2+}$ concn required for growth $(\mathrm{M})$ & 0.005 & 0.005 & ND & 0.005 \\
\hline Amino acids required for growth & + & + & + & - \\
\hline Oxidase & + & + & + & + \\
\hline Catalase & + & + & + & + \\
\hline Anaerobic growth & - & - & - & - \\
\hline Indole & - & - & - & - \\
\hline \multicolumn{5}{|l|}{ Carbohydrate utilization } \\
\hline Glucose & + & + & + & + \\
\hline Sucrose & + & + & + & + \\
\hline Lactose & + & - & ND & + \\
\hline Glycerol & + & + & ND & + \\
\hline
\end{tabular}

${ }^{a}$ Data from references 4 and 22

b Data from reference 4.

${ }^{c} \mathrm{ND}$, not determined. 
FIG. 3. Ch2 gene sequence coding for the $16 \mathrm{~S}$ rRNA molecule. The terminal sequences used as PCR primers and additional sequencing primers are underlined.

DNA was digested with restriction enzymes BamHI, SalI, and EcoRI. The digests were electrophoresed on $0.9 \%$ agarose gels, transferred to a nylon membrane (Zeta-Probe; Bio-Rad), and hybridized with nick-translated [ $\left.{ }^{32} \mathrm{P}\right] \mathrm{dATP}-$ labelled DNA (Bresatec, Adelaide, Australia) probes made from either the entire PCR fragment or a 362-bp BamHI fragment (near the $5^{\prime}$ end of the cloned gene) (22). Genomic DNA was examined for dam methylation by digestion with restriction enzymes $D p n I, M b o I$, and Sau3AI (12).

Strain $\mathrm{Ch} 2$ has been deposited in the Australian Collection of Microorganisms as strain ACM 3911.

Nucleotide sequence accession number. The $\mathrm{Ch} 216 \mathrm{~S}$ rRNA sequence has been deposited in the GenBank data base under accession number L00922.

\section{RESULTS AND DISCUSSION}

Ch2: source of isolate and cultural characteristics. To isolate hosts for halobacterial bacteriophages, we took samples of water from crystallization ponds containing up to $27 \%$ (wt/vol) salts at a marine saltern (Cheetham Salt, Ltd., Corio Bay, Geelong, Australia). Macroscopically, the water

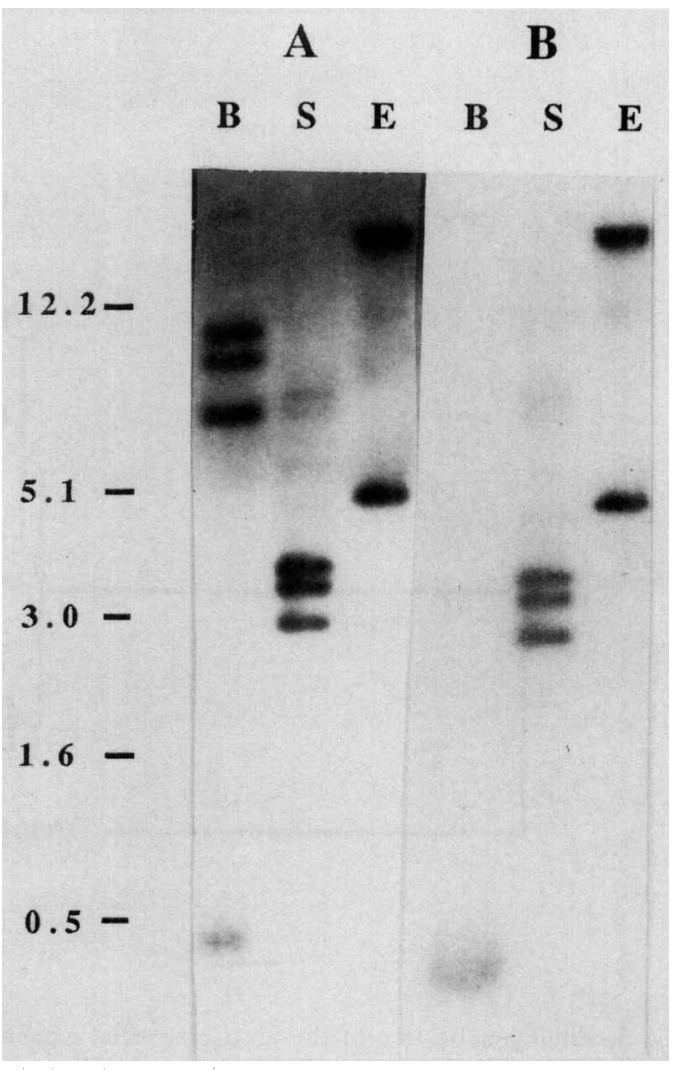

FIG. 4. Southern hybridization of $\mathrm{Ch} 2$ chromosomal DNA digests probed with the entire PCR fragment (A) or with a 362-bp BamHI fragment (B). The positions of size markers (in kilobases) are indicated on the left. Lanes B, BamHI digests; lanes S, SalI digests; lanes E, EcoRI digests.

was visibly pink, and as determined by light microscopy numerous halobacterium-like organisms were present along with small numbers of Dunaliella flagellates. Of the many halobacterium-like isolates that were cultured from these water samples, one isolate (Ch2) grew well in the presence of $18 \% \mathrm{SW}$ on minimal and rich (MGM) media and was susceptible to infection by halophage HF2 (14a).

On solid MGM at $37^{\circ} \mathrm{C}$, Ch2 produced dark red- or orange-pigmented colonies (diameter, 1.75 to $2.5 \mathrm{~mm}$ ) within 14 days, and in liquid MGM (shaken at $100 \mathrm{rpm}$ at $37^{\circ} \mathrm{C}$ ) $\mathrm{Ch} 2$ had a doubling time of 5 to $6 \mathrm{~h}$ during the logarithmic growth phase. $\mathrm{Ch} 2$ grew optimally in the presence of $\mathrm{NaCl}$ concentrations of 2.2 to $2.7 \mathrm{M}$ but poorly in the presence of $\mathrm{NaCl}$ concentrations of $2.0 \mathrm{M}$ or less (Fig. 1). Actively growing Ch2 cells were pleomorphic; the shapes included short rods and cup-shaped forms (Fig. 2A). Stationary-phase cultures contained predominantly long rods ( 5 by $0.5 \mu \mathrm{m})$ (Fig. 2B).

Biochemical and physiological characterization. Restriction enzymes Sau3AI and DpnI, but not $\mathrm{MboI}$, cut $\mathrm{Ch} 2$ genomic DNA (data not shown), indicating that this organism had a dam-methylated genome. A similar modification occurs in (and is limited to) the Halobacterium taxon consisting of Halobacterium saccharovorum, Halobacterium sodomense, and Halobacterium trapanicum $(4,12)$. The possession of such a modified genome placed $\mathrm{Ch} 2$ in this group. Further evidence of the relationship between $\mathrm{Ch} 2$ and this Halobacterium taxon came from studies performed with the recently isolated halophage HF2. The host range of HF2 was con- 


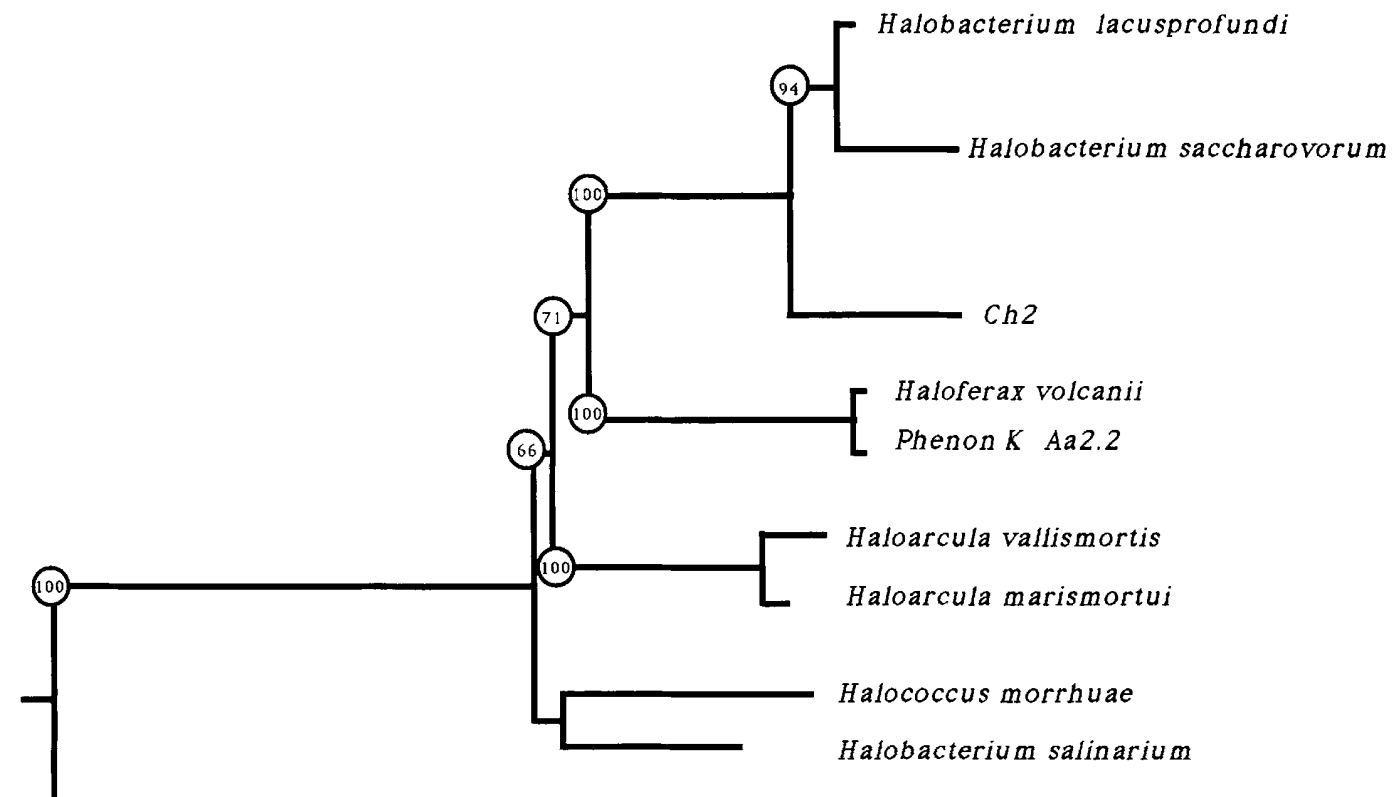

Methanogenium thermophilum

0.01

FIG. 5. Phylogenetic tree of the archaebacterial extreme halophile group. $M$. thermophilum is the closest methanogen. The values in circles are the parsimony bootstrap percentages (100 repetitions). Bar $=1$ nucleotide change per $100 \mathrm{bp}$.

fined to $\mathrm{Ch} 2$ and Halobacterium saccharovorum, although plating efficiencies on Halobacterium saccharovorum were low $\left(<10^{-9}\right)$. Host range mutants that exhibited increased plating efficiencies on Halobacterium saccharovorum could be readily isolated (14a). Such halophage typing provided a ready and simple means for identifying strain Ch2.

The physiological and biochemical features that characterize isolate $\mathrm{Ch} 2$ and distinguishing it from the other dammethylated halobacterial species are shown in Table 1 . The relatively high $\mathrm{NaCl}$ concentration required for growth, its ability to grow without added amino acids, its motility, and its morphological characteristics distinguish $\mathrm{Ch} 2$ from the other species in this taxon.

Ch2 was not able to grow under anaerobic conditions with or without nitrate present as an electron acceptor. Ch2 was susceptible to novobiocin (MIC, $0.0075 \mu \mathrm{g} / \mathrm{ml}$ ), mevilonic acid, and bacitracin and resistant to ampicillin, tetracycline, and kanamycin. Although the ability to grow in the absence

TABLE 2. Similarity matrix

\begin{tabular}{|c|c|c|c|c|c|c|c|c|c|c|}
\hline \multirow[b]{2}{*}{ Taxon } & \multicolumn{10}{|c|}{$\%$ Similarity to ${ }^{a}:$} \\
\hline & $\begin{array}{l}\frac{\pi}{5} \\
\frac{5}{5} \\
\frac{5}{5} \\
5\end{array}$ & 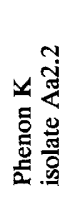 & 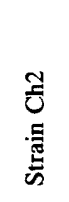 & 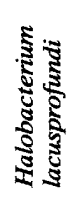 & 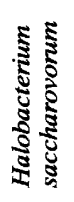 & 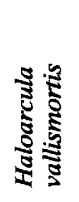 & 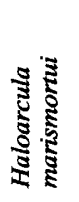 & 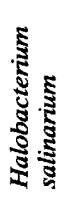 & 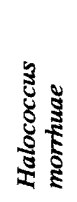 & 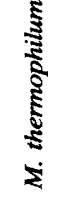 \\
\hline Haloferax volcanii & & 99.8 & 87.0 & 87.0 & 86.6 & 86.8 & 88.4 & 87.0 & 87.1 & 73.5 \\
\hline Phenon $\mathrm{K}$ isolate $\mathrm{Aa} 2.2$ & 99.8 & & 86.9 & 86.7 & 86.3 & 86.4 & 88.1 & 86.7 & 87.1 & 73.3 \\
\hline Strain Ch2 & 87.3 & 87.2 & & 93.7 & 94.0 & 85.1 & 83.9 & 85.8 & 82.7 & 72.7 \\
\hline Halobacterium lacusprofundi & 87.3 & 87.0 & 93.8 & & 97.5 & 84.4 & 84.1 & 85.3 & 81.9 & 71.3 \\
\hline Halobacterium saccharovorum & 86.9 & 86.6 & 94.0 & 97.5 & & 84.9 & 84.5 & 85.7 & 81.8 & 68.6 \\
\hline Haloarcula vallismortis & 86.9 & 86.6 & 85.4 & 84.7 & 85.2 & & 98.0 & 86.3 & 85.1 & 73.1 \\
\hline Haloarcula marismortui & 88.5 & 88.2 & 84.1 & 84.4 & 84.8 & 98.0 & & 87.2 & 86.5 & 73.7 \\
\hline Halobacterium salinarium & 87.1 & 86.9 & 86.0 & 85.6 & 86.0 & 86.5 & 87.3 & & 87.7 & 74.8 \\
\hline Halococcus morrhuae & 87.3 & 87.2 & 83.0 & 82.3 & 82.2 & 85.3 & 86.6 & 87.8 & & 72.3 \\
\hline M. thermophilum & 74.6 & 74.4 & 73.9 & 72.8 & 70.3 & 74.3 & 74.8 & 76.0 & 73.6 & \\
\hline
\end{tabular}

${ }^{a}$ Levels of similarity for members of the extreme halophile group of the archaebacteria based on 16S rRNA sequence data. The values on the lower left are percentages derived by using the nucleotide substitution model of Jukes and Cantor (9); the values on the upper right were calculated by using the Kimura model (10). 
of amino acids is more a characteristic of the genera Haloarcula and Haloferax (4), overall our results suggested that Ch2 should be placed in the dam-methylated taxon of the genus Halobacterium. To confirm this and definitively establish the taxonomic position of $\mathrm{Ch} 2$, the sequence of the 16S rRNA was determined.

Cloning, sequencing, and analysis of the $16 \mathrm{~S}$ rRNA gene. A PCR analysis of the Ch2 $16 \mathrm{~S}$ rRNA gene region yielded a single band (length, approximately $1,500 \mathrm{bp}$ ) which was cloned and sequenced. To confirm the identity of the clones and to eliminate the possibility of contamination (11), the sequence of a characteristic (i.e., variable) region of the $\mathrm{Ch} 2$ rRNA (positions 404 to 430) was determined by direct rRNA sequencing by using reverse transcriptase (6). The cloned DNA and directly determined rRNA sequences were the same.

The 1,469-bp gene sequence corresponding to the fulllength 16S rRNA is shown in Fig. 3. The final sequence was derived from at least two independently isolated clones. Three ambiguities between clones were detected; these ambiguities were most likely due to the inherent error rate found with Taq DNA polymerase (18) and were resolved by reference to additional clones.

The halobacteria possess variable numbers of genes encoding rRNAs, varying from one to four (21). In addition, the genome of Halobacterium marismortui contains two heterogeneous genes encoding 16S rRNAs (14). To determine the copy number of the Ch2 $16 \mathrm{~S}$ rRNA gene, we probed genomic digests with the entire PCR product or with a 362-bp Bam HI fragment from the $5^{\prime}$ end of the sequence (Fig. 4). The Bam HI and SalI lanes clearly showed the presence of three bands on different restriction fragments hybridizing with the probe. Although not clear in Fig. 4, the EcoRI digest also contained three bands (one at about $5 \mathrm{~kb}$ and two large, closely spaced bands running near the upper limit of the resolution of the gel). Since the $16 \mathrm{~S}$ rRNA sequence contains no internal SalI or EcoRI sites, the presence of three bands indicates that three separate $16 \mathrm{~S}$ rRNA genes are present in the $\mathrm{Ch} 2$ genome. No rRNA gene heterogeneity was observed in the sequences of several clones.

Halobacterial phylogeny. The position of $\mathrm{Ch} 2$ within the halobacterial taxon was investigated. All available archaeal 16S rRNA sequences were used, and an eubacterial thermophile (Thermotoga maritima) was used as an outgroup. Figure 5 shows the halophile clade and the closest methanogen (Methanogenium thermophilum), as well as the topology and branch lengths obtained by neighbor-joining methodologies. Maximum-parsimony approaches gave identical topologies. The levels of similarity between species are shown in Table 2.

Ch2 clusters with Halobacterium saccharovorum and Halobacterium lacusprofundi and is approximately equidistant from the type species of the genera Haloferax and Haloarcula. When parsimony confidence bootstrapping was used, the members of this clade clustered together all of the time (Fig. 5). The bootstrap values also revealed the possibility that the branching order of the genera Haloferax and Haloarcula and the genera Haloarcula and Halobacterium may be reversed. The clade containing $\mathrm{Ch} 2$ and Halobacterium saccharovorum is clearly separate from the clades containing the previously described genera and is separated from the type species of the genus Halobacterium by at least one bifurcation. These data justify grouping $\mathrm{Ch} 2$ with Halobacterium saccharovorum and support the suggestion of Lodwick et al. (13) that a new genus level classification is required. Unfortunately, the taxonomy of halobacteria is currently in such a state that large-scale revision is necessary (13), and this fact precludes us from proposing any formal taxonomic status for isolate $\mathrm{Ch} 2$. We designate strain $\mathrm{Ch} 2 \mathrm{a}$ new halobacterial isolate and suggest that when halobacterial taxonomy has been clearly resolved, this isolate should be included as a member of an appropriate genus level group.

\section{ACKNOWLEDGMENTS}

We thank Huang Jinan for doing the direct rRNA sequencing, David Spencer of the Department of Biochemistry, Dalhousie University, for performing the sequence comparisons and for expert advice and discussions, and V. Triantifillou for technical assistance. The assistance of the staff and management of Cheetham Salt Works, Geelong, Australia, is gratefully acknowledged.

This research was financed by a grant from the Australian Research Council. S.D.N. was supported by an Australian Postgraduate Research Award.

\section{REFERENCES}

1. Ausubel, F. M., R. Brent, R. E. Kingston, D. D. Moore, J. G. Seidman, J. A. Smith, and K. Struhl. 1989. Current protocols in molecular biology. John Wiley and Sons, New York.

2. Felsenstein, J. 1989. PHYLIP-phylogeny inference package (version 3.2). Cladistics 5:164-166.

3. Gerhardt, P., R. G. E. Murray, R. N. Costilow, E. W. Nester, W. A. Wood, N. R. Krieg, and G. B. Phillips (ed.). 1981. Manual of methods for general bacteriology. American Society for Microbiology, Washington, D.C.

4. Grant, W. D., and H. Larsen. 1990. Extremely halophilic archaebacteria, order Halobacteriales ord. nov., p. 2216-2233. In J. T. Staley, M. P. Bryant, N. Pfennig, and J. G. Holt (ed.), Bergey's manual of systematic bacteriology, vol. 3. Williams \& Wilkins, Baltimore.

5. Higgins, D. G., and P. M. Sharp. 1988. CLUSTAL: a package for performing multiple sequence alignment on a microcomputer. Gene 73:237-244.

6. Holmes, M. L., and M. L. Dyall-Smith. 1990. A plasmid vector with a selectable marker for halophilic archaebacteria. J. Bacteriol. 172: 756-761.

7. Holmes, M. L., G. J. Olsen, and M. L. Dyall-Smith. 1990. The halophilic archaebacteria $H b$. lacusprofundi and $H b$. saccharovorum are closely related: $16 \mathrm{~S}$ sequence comparison. Nucleic Acids Res. 18:4607.

8. Hui, I., and P. P. Dennis. 1985. Characterization of the ribosomal RNA gene clusters in Halobacterium cutirubrum. J. Biol. Chem. 260:899-906.

9. Jukes, T. H., and C. R. Cantor. 1969. Evolution of protein molecules. I, p. 21-132. In H. N. Munro (ed.), Mammalian protein metabolism. Academic Press, Inc., New York.

10. Kimura, M. 1980. A simple method for estimating evolutionary rate of base substitutions through comparative studies of nucleotide sequences. J. Mol. Evol. 16:111-120.

11. Kwok, S., and R. Higuchi. 1989. Avoiding false positives with PCR. Nature (London) 339:237-238.

12. Lodwick, D., H. N. M. Ross, J. E. Harris, J. W. Almond, and W. D. Grant. 1986. dam Methylation in the archaebacteria. J. Gen. Microbiol. 132:3055-3059.

13. Lodwick, D., H. N. M. Ross, J. A. Walker, J. W. Almond, and W. D. Grant. 1991. Nucleotide sequence of the $16 \mathrm{~S}$ ribosomal RNA gene from the haloalkaliphilic archaeon (archaebacterium) Natronobacterium-Magadii, and the phylogeny of halobacteria. Syst. Appl. Microbiol. 14:352-357.

14. Mylvaganam, S., and P. D. Dennis. 1992. Sequence heterogeneity between the two genes encoding 16S rRNA from the halophilic archaebacterium Haloarcula marismortui. Genetics 130:399-410.

14a.Nuttall, S. D., and M. L. Dyall-Smith. Submitted for publication.

15. Olsen, G. J., N. Larsen, and C. R. Woese. 1991. The ribosomal RNA database project. Nucleic Acids Res. 19:2017-2021. 
16. Oren, A., P. P. Lau, and G. E. Fox. 1988. The taxonomic status of "Halobacterium marismortui" from the Dead Sea: a comparison with Halobacterium vallismortis. Syst. Appl. Microbiol. 10:251-258.

17. Rodriguez-Valera, F., G. Juez, and D. J. Kushner. 1983. Halobacterium mediterranei spec. nov., a new carbohydrate-utilizing extreme halophile. Syst. Appl. Microbiol. 4:369-381.

18. Saiki, R. K., D. H. Gelfand, S. Stoffel, S. J. Scharf, R. Higuchi, G. T. Horn, K. B. Mullis, and H. A. Erlich. 1988. Primerdirected enzymatic amplification of DNA with a thermostable DNA polymerase. Science 239:487-491.

19. Sambrook, J., E. F. Fritsch, and T. Maniatis. 1989. Molecular cloning: a laboratory manual, 2nd ed. Cold Spring Harbor Laboratory Press, Cold Spring Harbor, N.Y.

20. Sanger, F., S. Nicklen, and A. R. Coulson. 1977. DNA sequencing with chain-terminating inhibitors. Proc. Natl. Acad. Sci.
USA 74:5463-5467.

21. Sanz, J. L., I. Marin, L. Ramirez, J. P. Abad, C. L. Smith, and R. Amils. 1988. Variable rRNA gene copies in extreme halobacteria. Nucleic Acids Res. 16:7827-7832.

22. Southern, E. M. 1975 . Detection of specific sequences among DNA fragments separated by gel electrophoresis. J. Mol. Biol. 98:503-517.

23. Tomlinson, G. A., and L. I. Hochstein. 1976. Halobacterium saccharovorum sp. nov., a carbohydrate-metabolizing, extremely halophilic bacterium. Can. J. Microbiol. 22:587-591.

24. Torreblanca, M., F. Rodriguez-Valera, G. Juez, A. Ventosa, M. Kamekura, and M. Kates. 1986. Classification of non-alkaliphilic halobacteria based on numerical taxonomy and polar lipid composition, and description of Haloarcula gen. nov. and Haloferax gen. nov. Syst. Appl. Microbiol. 8:89-99. 